\title{
Characteristics of damage to buildings by debris flows on 7 August 2010 in Zhouqu, Western China
}

\author{
K. H. Hu${ }^{1,2}$, P. Cui ${ }^{1,2}$, and J. Q. Zhang ${ }^{1,2}$ \\ ${ }^{1}$ Key Laboratory of Mountain Hazards and Earth Surface Processes, Chinese Academy of Sciences, Chengdu 610041, China \\ ${ }^{2}$ Institute of Mountain Hazards and Environment, Chinese Academy of Sciences and Ministry of Water Conservancy, \\ Chengdu 610041, China
}

Correspondence to: K. H. Hu (khhu@imde.ac.cn)

Received: 13 February 2012 - Revised: 10 May 2012 - Accepted: 20 June 2012 - Published: 18 July 2012

\begin{abstract}
A debris-flow catastrophe hit the city of Zhouqu, Gansu Province, western China, at midnight on $7 \mathrm{Au}$ gust 2010 following a local extreme rainfall of $77.3 \mathrm{~mm} \mathrm{~h}^{-1}$ in the Sanyanyu and Luojiayu ravines, which are located to the north of the urban area. Eight buildings damaged in the event were investigated in detail to study the characteristics and patterns of damage to buildings by debris flows. It was found that major structural damage was caused by the frontal impact of proximal debris flows, while non-structural damage was caused by lateral accumulation and abrasion of sediment. The impact had a boundary decreasing effect when debris flows encountered a series of obstacles, and the interpositioning of buildings produced so-called back shielding effects on the damage. Impact, accumulation, and abrasion were the three main patterns of damage to buildings in this event. The damage scale depended not only on the flow properties, such as density, velocity, and depth, but also on the structural strength of buildings, material, orientation, and geometry. Reinforced concrete-framed structures can effectively resist a much higher debris-flow impact than brickconcrete structures. With respect to the two typical types of structure, a classification scheme to assess building damage is proposed by referring to the Chinese Classification System of Earthquake Damage to Buildings. Furthermore, three damage scales (major structural, minor structural, and nonstructural damage) are defined by critical values of impact pressure. Finally, five countermeasures for effectively mitigating the damage are proposed according to the on-site investigation.
\end{abstract}

\section{Introduction}

Human lives and constructions in debris-flow prone mountain areas are regularly subject to debris-flow hazards. In recent decades, many debris-flow tragedies have been reported all over the world (Pierson et al., 1990; Wu et al., 1993; Wieczorek et al., 2001; Zaporozhchenko, 2003; Zanchetta et al., 2004; Evans et al., 2009). For instance, a large-scale debris flow occurred at Liziyida Ravine, a tributary of the Dadu River in Sichuan Province, China, on 9 July 1981 and destroyed a railway bridge, leading to the overturning of a moving train and 275 deaths (Wu et al., 1993). Another wellknown tragedy was in the Vargas State of Venezuela in December 1999 (Wei et al., 2000; Wieczorek et al., 2001). Two densely populated towns completely disappeared, and the population of Vargas decreased by $10 \%$ during this event.

The elements exposed to debris-flow hazards include structures and infrastructures such as highways, railways, mines, and reservoirs. Compared to strong structural facilities such as railway bridges, common civil structures are more easily damaged by debris flows. Wei et al. (2000) reported that a ten-storey reinforced concrete building was partly destroyed by the debris flows of 1999 in Vargas. Some specific cases of building damage by debris flows were investigated, such as the disaster of July 1988 in Kake Town, Hiroshima Prefecture, Japan (Mizuyama and Ishikawa, 1990), the lahars of 13 November 1985 in Nevado del Ruiz, Colombia (Mileti et al., 1991), and the volcaniclastic flows of May 1998 in the Sarno area, Italy (Toyos et al., 2003; Zanchetta et al., 2004). Progress has been made in quantifying the vulnerability of buildings to debris flows (Fuchs et al., 2007; Haugen and Kaynia, 2008; Totschnig et al., 2011; Quan Luna

Published by Copernicus Publications on behalf of the European Geosciences Union. 
et al., 2011; Jakob et al., 2012). Fuchs et al. (2007) derived an empirical intensity-vulnerability relationship from data of the 16 August 1997 debris-flow event in the Austrian Alps. Haugen and Kaynia (2008) proposed a model for assessing the vulnerability of structures to debris-flow impact by referring to HAZUS damage state probabilities and tested it by applying it to the debris-flow events of May 1998 in the Sarno area. Quan Luna et al. (2011) obtained three different empirical vulnerability curves as functions of debris-flow depth, impact pressure, and kinematic viscosity by numerical modelling and a physical damage investigation of the Selvetta debris-flow event that occurred in the central part of the Valtellina Valley, Northern Italy. Jakob et al. (2012) defined four damage classes, from minor sedimentation to complete building destruction, and related them with an intensity index represented by the impact force of debris flows. Although these empirical relationships can be applied in practice to some extent, most of the previous studies have focused on empirical relationships between the hazard magnitude and the respective degree of loss that was caused by recent events. As a result, the proposed empirical vulnerability functions do not consider the particular characteristics of buildings at risk, such as their geometry, layout, and geographic position.

On 7 August 2010, a destructive debris flow hit the city of Zhouqu, Gansu Province, western China. A total 1765 fatalities were claimed, 33 buildings with a total area of $11472 \mathrm{~m}^{2}$ were completely destroyed, and 20 buildings were partially damaged. Most deaths and property losses were associated with the damage to buildings. In this paper, the characteristics and patterns of building damage in the Zhouqu event, investigated by the method of field reconnaissance and remote sensing, are described to provide useful information for vulnerability analysis and future urban planning. Finally, a classification scheme for assessing building damage is proposed with respect to brick-concrete and reinforced concrete structural buildings, which are the most common structures in the mountain areas of China.

\section{Study area}

The study area is located in Zhouqu County, Gansu Province, western China, including the Sanyanyu and Luojiayu catchments, which are tributaries on the northern of the Bailong River (Fig. 1). The area features alpine mountains and deeply incised canyons, with an elevation between 1200 and $4200 \mathrm{~m}$ a.s.1. A $1.2-\mathrm{km}^{2}$ ancient alluvial fan formed by floods and debris flows at the mouth of the Sanyanyu and Luojiayu is the largest flat area in the county, and was therefore chosen as the location of the capital of Zhouqu County. As a result, debris-flow hazards from the two catchments may directly threaten the urban area of the capital. The basic morphologic parameters of the two catchments are listed in Table 1.

The area is located in a highly active earthquake zone where six earthquakes with $M_{\mathrm{s}}>7.0$ have been recorded

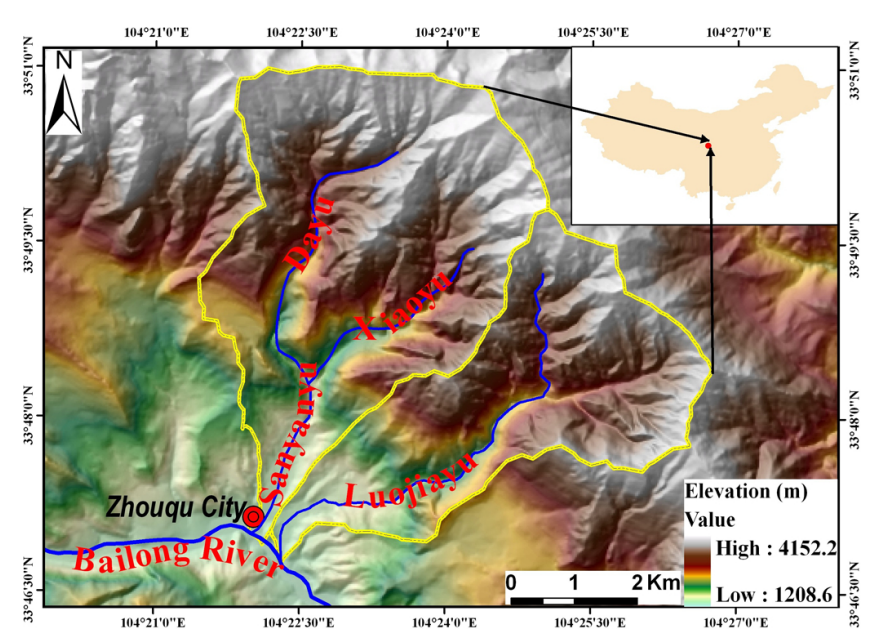

Fig. 1. Location of the study area (Dayu and Xiaoyu are two main branches of the Sanyanyu).

in history. Three active east-western faults pass through the area. Exposed rocks consist of phyllite, limestone, shale, and slate, which are easily transformed into clay and detritus by weathering. The quaternary strata are composed of river terraces, lacustrine, colluvial, and loess deposits. The climate is warm and semi-humid, influenced by the East Asian monsoon. The annual rainfall is $434 \mathrm{~mm}$, approximately $75 \%$ of which is concentrated between May and October. Torrential and moderate rains with high intensity often occur in the flood season. The highest recorded $24-\mathrm{h}$ and $1-\mathrm{h}$ rainfall intensities before the 7 August 2010 event were $62.9 \mathrm{~mm}$ and $40.7 \mathrm{~mm}$ in 1994. Under such physiographic, geological, and climatic settings, Sanyanyu and Luojiayu are regularly prone to debris flows; 11 destructive events occurred in the 20th century. However, such large-scale debris-flow events as on 7 August 2010 were unexpected by local residents.

\section{The 7 August 2010 event}

The debris flows occurred at approximately $23: 35 \mathrm{LT}$ on 7 August 2010 and were presumably triggered by a local rainstorm, with $77.3 \mathrm{~mm}$ of rainfall between 23:00 and 24:00 LT and $96.7 \mathrm{~mm}$ accumulated rainfall from 20:00 LT on 7 August to 04:00 LT on 8 August (Qu et al., 2010; Zhao and Cui, 2010). Field investigation and satellite image interpretation indicated that the debris flows were initiated by the upstream torrent. The main debris sources were avalanches, landslides, colluvium, and weathered rock. Large slope gradients and narrow downstream channels resulted in high mobility of debris flows. More importantly, a cascade of natural rock-filled dams and silt-trapping dams burst and significantly increased the discharge of the debris flow in the Sanyanyu up to $1485 \mathrm{~m}^{3} \mathrm{~s}^{-1}$ and the event magnitude up to 2.2 million $\mathrm{m}^{3}$. The density was estimated as $2000 \mathrm{~kg} \mathrm{~m}^{-3}$ by 
Table 1. Basic morphologic parameters of Sanyanyu and Luojiayu catchments.

\begin{tabular}{lrrrrrr}
\hline & $\begin{array}{r}\text { Catchment } \\
\text { area } \\
\left(\mathrm{km}^{2}\right)\end{array}$ & $\begin{array}{r}\text { Average gradient } \\
\text { of main channel } \\
(\%)\end{array}$ & $\begin{array}{r}\text { Mainstream } \\
\text { length } \\
(\mathrm{km})\end{array}$ & $\begin{array}{r}\text { Elevation } \\
\text { summit } \\
(\mathrm{m})\end{array}$ & $\begin{array}{r}\text { Elevation } \\
\text { outlet } \\
(\mathrm{m})\end{array}$ & $\begin{array}{r}\text { Relative } \\
\text { relief } \\
(\mathrm{m})\end{array}$ \\
\hline Sanyanyu & 25.75 & 24.1 & 10.4 & 3828 & 1340 & 2488 \\
Luojiayu & 16.14 & 25.8 & 9.5 & 3780 & 1320 & 2460 \\
\hline
\end{tabular}

analysing sediment samples taken from debris-flow deposits two days after the event (Hu et al., 2010).

The debris flows hit three suburban villages and the densely populated zone of the city. Subsequently, the debris flowed into Bailong River and formed a 1.2-km-long dam completely blocking the river (Fig. 2), inundating nearly onethird of the urban area. As of 1 September 2010, the disaster has affected 4496 families and resulted in 1471 dead and 294 missing persons. The event also destroyed 233.4 acres of farmland and damaged 53 buildings, making it the severest debris-flow disaster since 1949.

Most of the buildings on both sides of the channel were buried or completely destroyed (Fig. 2). Eight surviving buildings were chosen as study cases. Although severely damaged, part of information on the damage can be recovered from the photos. The buildings represented three kinds of structure (brick-concrete, reinforced-concrete frame, and brick masonry), two of which are common in the mountain areas of China (Table 2).

\section{Characteristics and mitigation of building damage}

\subsection{Damage characteristics}

Damage to the eight buildings was characterized by four features: frontal impact, dominant in the proximal portion of debris flows; accumulation and abrasion, dominant in the distal portion of debris flows; the boundary decreasing effect; and the back shielding effect. The most severe damage occurred to buildings that were located around the main streamline and impacted by proximal debris flows in which most of the mass and energy was concentrated (Fig. 3). For example, buildings A, B, and E were located in the centre of the flooded areas. The bottom two and half storeys of building A at Luojiayu were partially destroyed by the impacting forces, and then the remaining upper floors collapsed (Fig. 3a). Building B was located $60 \mathrm{~m}$ north of building E. Both were heavily damaged by the direct impact of the main flows at an angle of approximately $90^{\circ}$. In these cases, the damage due to frontal or orthogonal impact is far greater than that due to accumulation and abrasion. Moreover, the scale of damage the two buildings experienced is different and is related to their configuration. Building $\mathrm{E}$ was toppled and pushed $18 \mathrm{~m}$ downstream (Fig. 3c), whereas only the upstream wall and corridor of building B were destroyed.

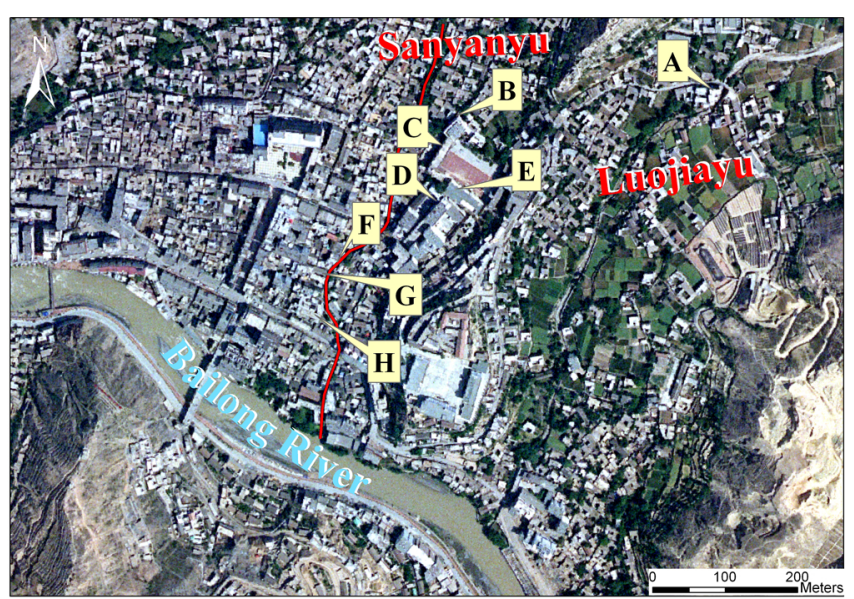

(a)

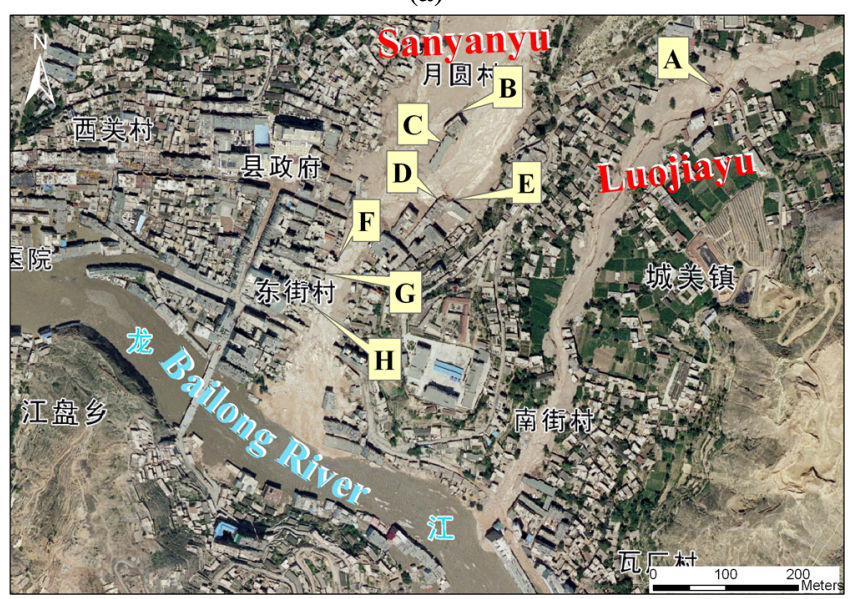

(b)

Fig. 2. Damage to buildings in Zhouqu city by the debris flows on 7 August 2010. (a) ALOS satellite image on 10 March 2010. (b) Aerial photo on 10 August 2010 published by the National Administration of Surveying, Mapping and Geoinformation. The red solid line in (a) indicates the drainage channel before the event. The labels A-H indicate the locations of the eight buildings presented in this case study. Note that a large deviation is seen between the location of Building $\mathrm{E}$ in (a) and (b) because the building was moved downstream by debris flows.

Besides stronger foundations, building B's configuration enabled it to resist the impact better than building E. The longitudinal orientation of $\mathrm{E}$ was normal to the main flow direction and had a larger contact area, which greatly increased 
Table 2. Description of damage to the eight buildings by debris flow.

\begin{tabular}{|c|c|c|c|c|}
\hline Building & Style & Structure & Damage & Catchment \\
\hline A & Seven-storey residential building & brick-concrete & $\begin{array}{l}\text { Structural damage: two and half } \\
\text { storeys at the bottom were } \\
\text { destroyed, and the left storeys } \\
\text { collapsed }\end{array}$ & Luojiayu \\
\hline B & Six-storey residential building & reinforced-concrete frame & $\begin{array}{l}\text { Structural damage: the front walls } \\
\text { and two sides of this building were } \\
\text { partially damaged }\end{array}$ & Sanyanyu \\
\hline $\mathrm{C}$ & $\begin{array}{l}\text { Old four-storey classroom building } \\
\text { of Chengguan primary school }\end{array}$ & reinforced-concrete frame & $\begin{array}{l}\text { Non-structural damage: the first } \\
\text { storey was completely buried by } \\
\text { depositional debris }\end{array}$ & Sanyanyu \\
\hline $\mathrm{D}$ & Six-storey residential building & brick-concrete & $\begin{array}{l}\text { Structural damage: the whole } \\
\text { building collapsed and the bottom } \\
\text { four storeys disappeared }\end{array}$ & Sanyanyu \\
\hline $\mathrm{E}$ & $\begin{array}{l}\text { New six-storey classroom building } \\
\text { of Chengguan primary school }\end{array}$ & reinforced-concrete frame & $\begin{array}{l}\text { Structural damage: the foundation } \\
\text { was undermined and the whole } \\
\text { building toppled }\end{array}$ & Sanyanyu \\
\hline $\mathrm{F}$ & Four-storey residential building & reinforced-concrete frame & $\begin{array}{l}\text { Structural damage: the three storeys } \\
\text { at the bottom were destroyed, but } \\
\text { the top storey did not collapse }\end{array}$ & Sanyanyu \\
\hline G & Two-storey residential building & brick masonry & $\begin{array}{l}\text { Non-structural damage: the front } \\
\text { and side walls were destroyed }\end{array}$ & Sanyanyu \\
\hline $\mathrm{H}$ & $\begin{array}{l}\text { Three rows of five-storey terraced } \\
\text { buildings }\end{array}$ & reinforced-concrete frame & $\begin{array}{l}\text { Structural damage: part of the } \\
\text { beams and columns of the build- } \\
\text { ing framework were broken, but the } \\
\text { buildings did not fall down }\end{array}$ & Sanyanyu \\
\hline
\end{tabular}

the gravity moment of the building. A larger contact area results in a greater impact force, and a smaller gravity moment reduces the ability of the building to resist overturning. The mud trace on building B's wall indicated that the maximum flow depth and run-up height were approximately nine metres (three storeys high) and six metres (two storeys high), respectively (Fig. 3b). The flow velocity before impact was estimated as $10.84 \mathrm{~m} \mathrm{~s}^{-1}$, according to the kinetic-potential energy transformation formula $v=\sqrt{2 g h}$, where $g$ is the acceleration due to gravity and $h$ is the run-up height. Then, the maximum impact pressure exerted on building $B$ at the stagnation point was roughly estimated to be $2.44 \times 10^{5} \mathrm{~Pa}$ by using $P=\rho v^{2}+0.5 \rho g H$ (Zanchetta et al., 2004), where $P$ is the impact pressure, $\rho$ is the debris-flow density, and $H$ is the flow depth.

When the main flow direction is parallel to the contact face or the building is impacted by distal debris flows, the damage is dominated by lateral abrasion or accumulation. As such, the sidewall of building B was abraded, but only the windows and doors were destroyed (Fig. 4a). Damage caused by lateral accumulation and abrasion is far smaller than that caused by frontal impact, because the velocity component along the main stream is higher than the lateral or transverse component. Building F, a four-storey residential building with a reinforced-concrete frame, was obviously stronger than building $\mathrm{G}$, an old two-storey brick masonry building. However, the protruding portion of building $\mathrm{F}$ was destroyed under the frontal impact of proximal debris flows, while the structure of building $G$ had no damage, only being buried half a storey deep by distal debris flows (Fig. 4bc). The first two features suggest that the vulnerability has a clear dependence on the debris-flow portions. For example, Michael-Leiba et al. (2003) distinguished the damage by proximal debris flows from that by distal debris flows and defined the vulnerabilities for elements at risk susceptible to proximal and distal debris flows by values of 1 and 0.1 , respectively.

The third noticeable feature was the longitudinal boundary decreasing effect. It is evident in the damage to building $\mathrm{H}$, three rows of five-storey terraced buildings with reinforcedconcrete frames (Fig. 5). The total length of building $\mathrm{H}$ was $24 \mathrm{~m}$ (Fig. 4c). Debris flows destroyed three storeys of the first row and two storeys of the second row. However, for the third row, no pillars were destroyed and only the first storey was buried. The losses decreased by one-third progressively per $8 \mathrm{~m}$ along the boundary of building $\mathrm{H}$. That means the energy consumed by destroying the pillars of the first two storeys reduced the impact force of the flow. After impacting 


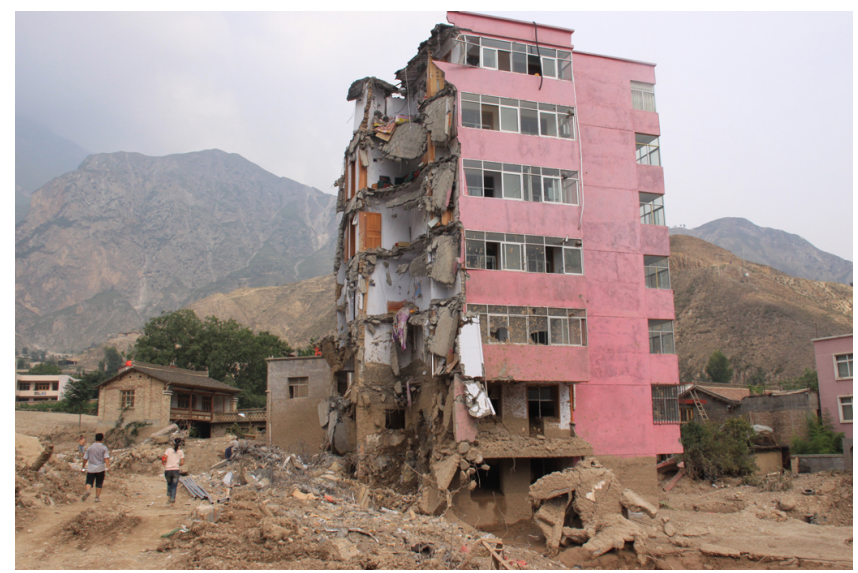

(a)

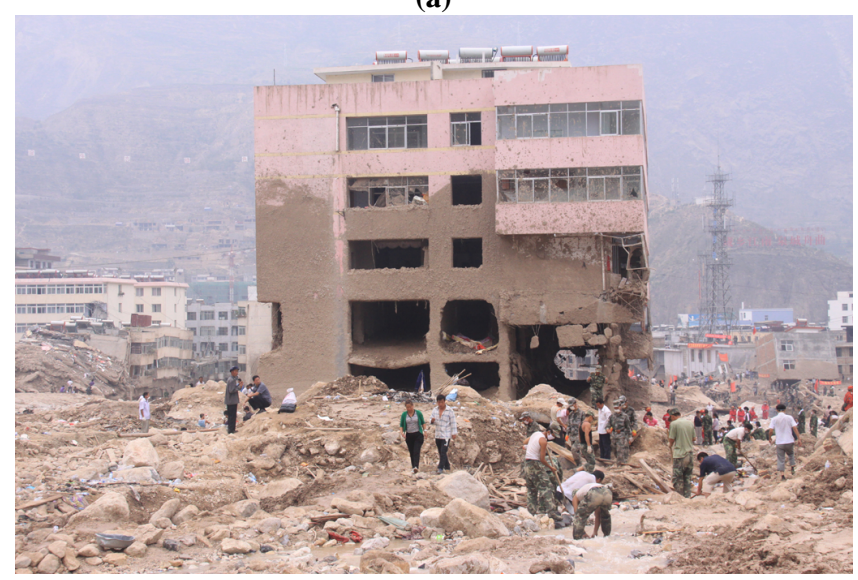

(b)

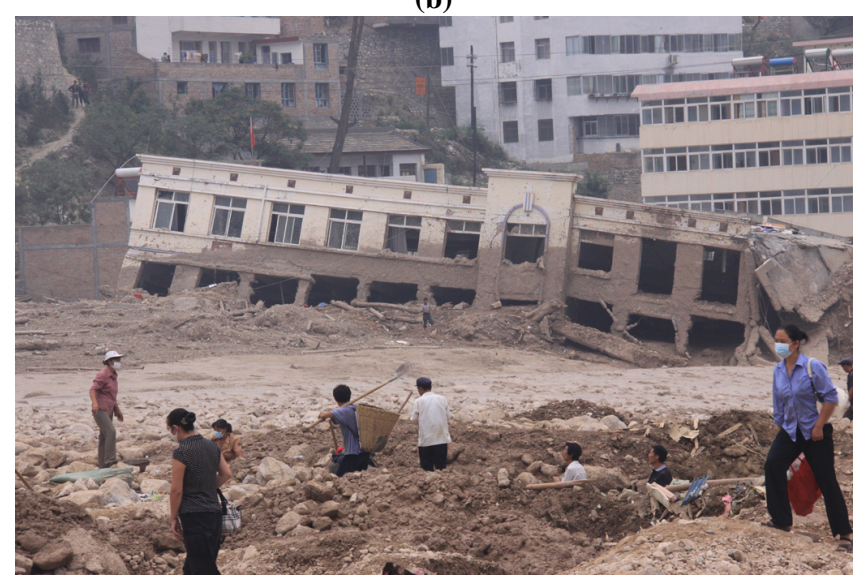

(c)

Fig. 3. Damage to the three buildings impacted head-on by proximal debris flow. (a) Building A. (b) Building B. (c) Building E. One storey is approximately $3-\mathrm{m}$ high.

the front two rows, the flow bodies on the boundary decelerated and did little harm to the last row. However, the flows destroyed a building $20 \mathrm{~m}$ downstream of building $\mathrm{H}$. This shows that the boundary part of the flows can gain kinetic energy from gravitational energy and the central part when

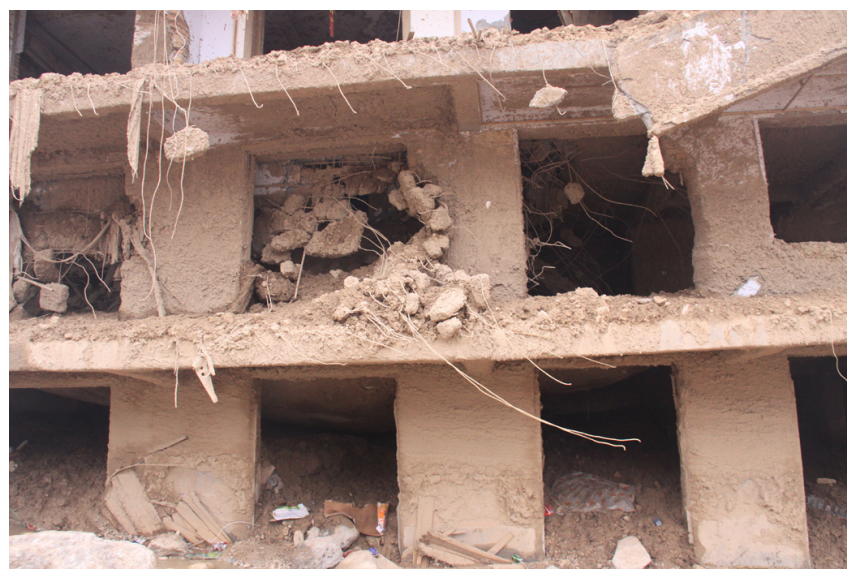

(a)

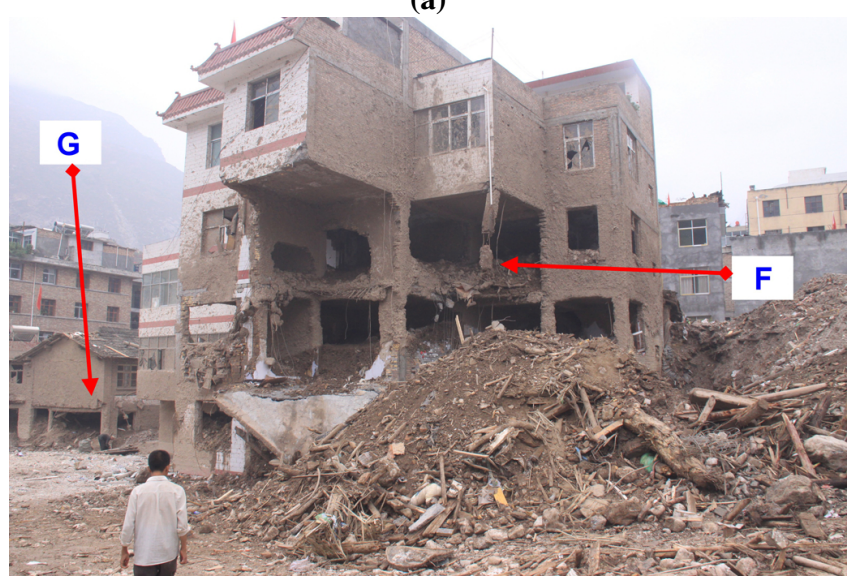

(b)

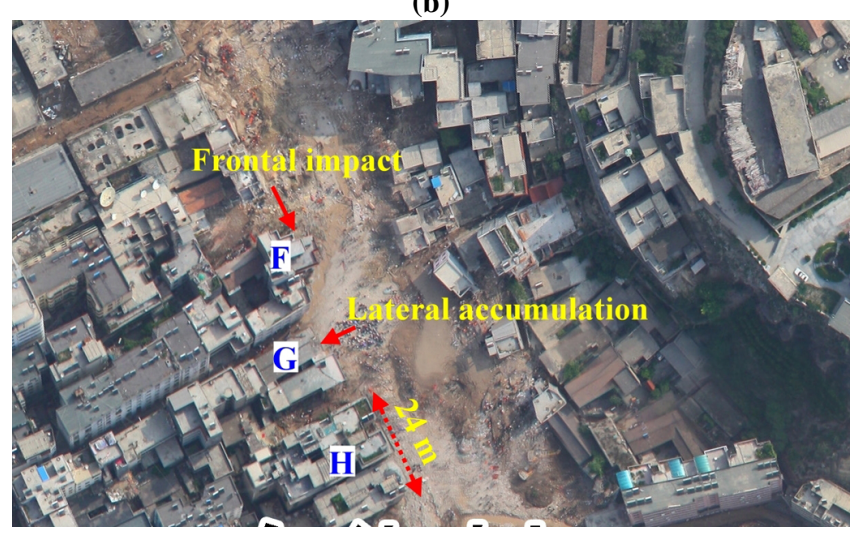

(c)

Fig. 4. Comparison of damage to buildings by frontal impact with damage by lateral abrasion and accumulation. (a) Sidewall of building B. (b) Buildings $\mathrm{F}$ and $\mathrm{G}$. (c) Relative position of buildings $\mathrm{F}$ and $\mathrm{G}$ on an aerial photo.

the flows keep moving downstream for a distance without any boundary interferences. In practice, it is very difficult to quantify the longitudinal boundary decreasing effect.

If a building's size is large enough, it can disturb the flow field. A buffer zone forms behind the building where flow velocity and depth are far smaller than in the undisturbed zone. 


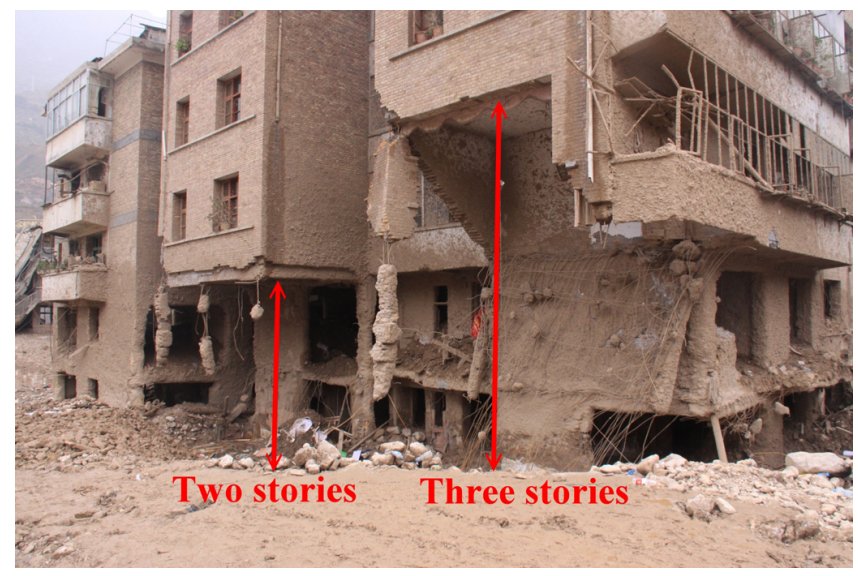

Fig. 5. Differing extent of damage to building $\mathrm{H}$ by longitudinally decreasing impact force.

Thus, buildings in the buffer zone suffer less damage than those in the undisturbed zone. This feature, called the back shielding effect, is illustrated in Fig. 6a, which shows that building $\mathrm{C}$, next to the heavily damaged building $\mathrm{B}$, suffered no damage apart from its first storey being buried. However, the outcome of the back shielding effect depends on the quality of the upstream building. If the upstream building is not strong enough, secondary damage may occur. The collapsed building $\mathrm{E}$ is a failed case of the shielding effect. Building $\mathrm{E}$ was initially knocked down by debris flows because its foundation was not good, and then it struck one side of building D, a six-storey residential building behind $\mathrm{E}$, toppling $\mathrm{D}$ instead of protecting it. The bottom four floors of $\mathrm{D}$ were pushed down like stacked dominoes because the building did not have a reinforced concrete frame structure and was unable to withstand horizontal thrust. The walls between any neighbouring two of the bottom four floors collapsed, and the floors were displaced downward by approximately two metres. Only the top two floors were relatively unaffected (Fig. 6b). In contrast to the shielding effect, the protruding part of a building is more easily damaged, as shown by building $\mathrm{F}$ (Fig. 4b).

\subsection{Mitigation}

Debris flow, a rapid two-phase flow with a high sediment concentration, is very different from other mountain hazards such as torrential flood, snow avalanche, and rock falls. The damage patterns or ways to civil constructions due to the hazards are also different, and necessary to special mitigation actions. On the basis of the hazard characteristics, Spence et al. (2004) proposed four mitigation measures against pyroclastic flow, namely evacuation, remaining indoors, reducing infiltration, and reinforcing openings. Holub et al. (2012) studied protection measures for a residential building to resist impact forces experienced with respect to fluvial sediment transport related to torrents and snow avalanches. For

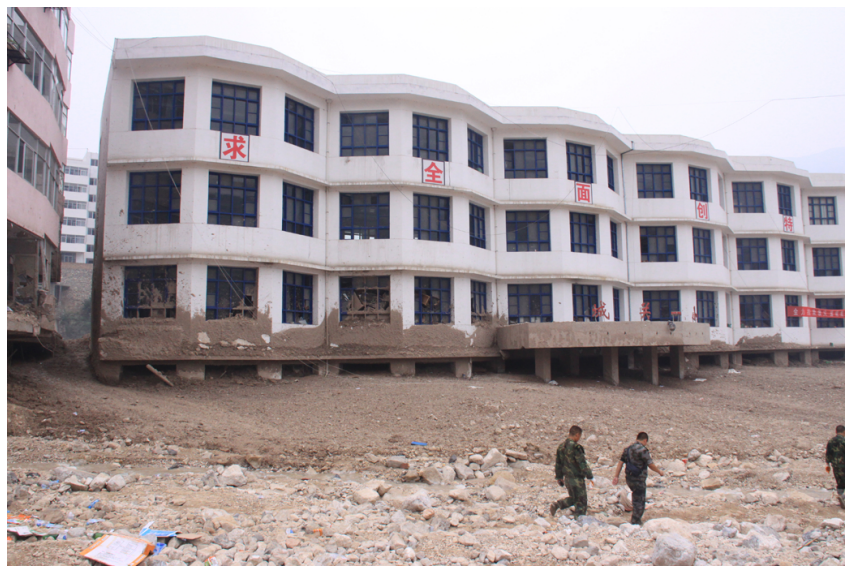

(a)

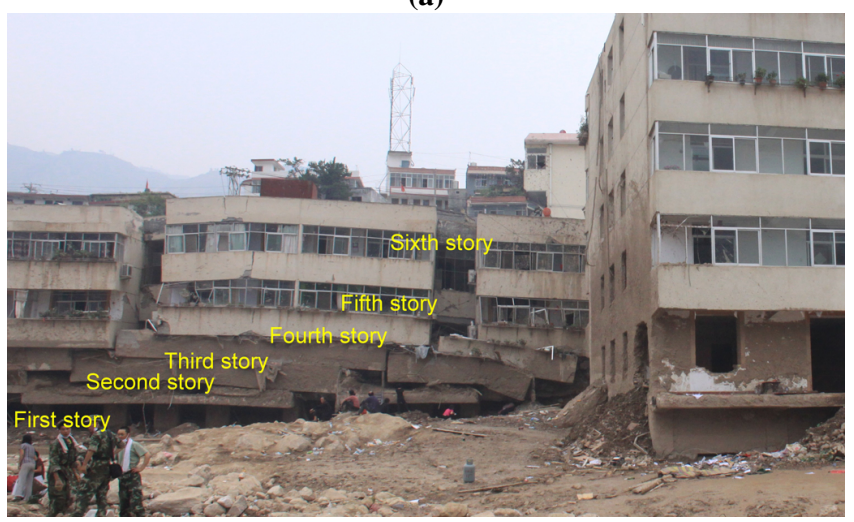

(b)

Fig. 6. Back shielding effects. (a) Building C. (b) Building D. Building D was knocked down by the collapse of building E, a case of a failed shielding effect.

debris flow, the fluid component exerts hydrostatic and dynamic pressure on the surface of obstacles, while the solid component collides with and abrades obstacles at the contact surface. A debris flow is also a non-Newtonian fluid that has non-zero yield stress and deposits material on a gentle slope. Corresponding to these characteristics, there are three main damage patterns, i.e. impact, accumulation, and abrasion. Moreover, different types of debris flows have their own damage patterns. Mileti et al. (1991) gave an instance of oxidation of metallic elements due to the low $\mathrm{PH}$ of the fluids in the lahar of Nevado del Ruiz, Colombia, in 1985. However, for rainfall-induced debris flows such as at Zhouqu, there are no such thermal or chemical damage patterns. Our proposed countermeasures are specific to rainfall-induced debris flows and densely populated towns, and only address the damage patterns of impact, accumulation, and abrasion.

Corresponding to the characteristics and patterns illustrated in the Zhouqu event, five effective countermeasures for mitigating damage to buildings are proposed: (1) reduce the contact surface normal to the flow direction by aligning the long axis of the building with the flow; (2) use a reinforced 
Table 3. Classification of damage to civil architecture by debris flow.

\begin{tabular}{|c|c|c|c|c|c|}
\hline \multirow{2}{*}{ Damage class } & \multicolumn{2}{|c|}{ Damage description } & \multirow{2}{*}{ Damage scale } & \multicolumn{2}{|c|}{ Impact pressure $(\mathrm{kPa})$} \\
\hline & Brick-concrete & $\begin{array}{l}\text { Reinforced-concrete } \\
\text { frame }\end{array}$ & & Brick-concrete & $\begin{array}{r}\text { Reinforced-concrete } \\
\text { frame }\end{array}$ \\
\hline Complete & $\begin{array}{l}\text { Less than } 50 \% \text { of the building } \\
\text { survives, or two or more storeys } \\
\text { are buried }\end{array}$ & $\begin{array}{l}\text { Less than } 50 \% \text { of the building's } \\
\text { framework survives, or two or } \\
\text { more storeys are buried }\end{array}$ & $\begin{array}{l}\text { I: Major structural } \\
\text { damage or loss of } \\
\text { functionality }\end{array}$ & $>18$ & $>110$ \\
\hline Heavy & $\begin{array}{l}\text { A majority of bearing walls col- } \\
\text { lapse, most walls are broken, } \\
\text { part of the roof falls in, or more } \\
\text { than one storey is buried }\end{array}$ & $\begin{array}{l}\text { A majority of columns and } \\
\text { beams are broken, most walls } \\
\text { are broken, part of the roof falls } \\
\text { in, or more than one storey is } \\
\text { buried }\end{array}$ & & & \\
\hline Moderate & $\begin{array}{l}\text { A minority of bearing walls are } \\
\text { damaged, some walls are bro- } \\
\text { ken, or less than one storey is } \\
\text { buried }\end{array}$ & $\begin{array}{l}\text { A minority of columns and } \\
\text { beams are damaged, some walls } \\
\text { are broken, or less than one } \\
\text { storey is buried }\end{array}$ & $\begin{array}{l}\text { II: Minor structural } \\
\text { damage, loss of } \\
\text { some functionality, } \\
\text { could be repaired } \\
\text { with major effort }\end{array}$ & $6-18$ & $35-110$ \\
\hline Slight & $\begin{array}{l}\text { Only nonbearing walls are par- } \\
\text { tially damaged, or less than half } \\
\text { a storey is buried }\end{array}$ & $\begin{array}{l}\text { Columns and beams are intact, } \\
\text { only some walls are partially } \\
\text { damaged, or less than half a } \\
\text { storey is buried }\end{array}$ & $\begin{array}{l}\text { III: Non-structural } \\
\text { damage and } \\
\text { reusable }\end{array}$ & $0-6$ & $0-35$ \\
\hline Very slight & $\begin{array}{l}\text { Nonbearing and bearing walls } \\
\text { are intact, only windows and } \\
\text { doors are damaged, some } \\
\text { sediment accumulation on the } \\
\text { ground }\end{array}$ & $\begin{array}{l}\text { Columns, beams, and walls are } \\
\text { intact; only windows and doors } \\
\text { are damaged; some sediment } \\
\text { accumulation on the ground }\end{array}$ & & & \\
\hline
\end{tabular}

concrete structure; (3) avoid protruding parts in the design, as far as possible; (4) allow a sufficient distance between two buildings in the transverse direction, and place them closer together along the main flow direction; (5) avoid using the first floor of high buildings as living or business space. The first four measures are mainly related to the configuration, structure, position relative to the central flow, and topology of buildings. Structural protection for individual buildings, such as the incorporation of additional constructional elements (Holub et al., 2012), is beyond the scope of this paper. The fifth measure is motivated by the fact that most casualties and losses were sustained on the first and second floors.

\section{Classification of building damage}

In order to evaluate building damage due to debris-flow hazards, it is necessary to establish a system of classifying building damage. However, damage depends not only on the properties of the flow, such as density, velocity, and depth, but also on the building's orientation, structural strength, and regularity. Compared with brick-concrete buildings, which have little resistance to horizontal thrust, buildings with reinforced concrete frames can resist much greater debrisflow impact and hence suffer less damage. Thus, it is impossible to compare different damage to different structures under a unique standard because of the complexity of the buildings' structure and material. Here, for simplicity, two building structures, brick-concrete and reinforced-concrete frame, both typical in China's mountainous areas, are considered. Concerning these two structures, a classification scheme is proposed with reference to China's Classification System of Earthquake Damage to Buildings (Table 3). The scheme defines five damage classes: complete, heavy, moderate, slight, and very slight.

Impact force is the most important index for assessing damage to buildings by debris flows. Zanchetta et al. (2004) investigated building damage in the 5-6 May 1998 volcaniclastic debris flows in the Sarno area and found that only minor damage was caused to structures when the impact pressure was lower than $35 \mathrm{kPa}$. Wei et al. (2006) demonstrated by impact experiments that the ultimate bearing pressure of a reinforced concrete frame building is $110.56 \mathrm{kPa}$ and that of brick-concrete is $18.22 \mathrm{kPa}$. According to previous classifications (Toyos et al., 2003; Zanchetta et al., 2004; Jakob et al., 2011), the five classes were reduced to three damage scales that can be roughly quantified by the results of Zanchetta et al. (2004) and Wei et al. (2006). The values of the ultimate bearing pressure serve as the impact pressure lower bound of scale I for each of the structures. The lower bound of scale II for the reinforced-concrete frame is set to $35 \mathrm{kPa}$. Given that the brick-concrete strength is proportional to the reinforced-concrete frame, the lower limit of scale II for the brick-concrete structure is also set to one-third of its ultimate pressure (Table 3). 
The pressure limit of scale I on reinforced-concrete structures is higher than proposed by other documents. Valentine (1998) related damage to structures by pyroclastic flows with nuclear weapons experiments and indicated that $35 \mathrm{kPa}$ was the upper limit for any kind of structure. Wilhelm (1998) and Barbolini et al. (2004) assigned a vulnerability of 1.0 at $34 \mathrm{kPa}$ for snow avalanches. As mentioned above, different hazards have different damage patterns and characteristics. For example, thermal damage by pyroclastic flows or loads on roofs by snow avalanches play an important role, together with impact, and may effectively reduce the horizontal pressure limit buildings can resist. The vulnerability function derived from debris-flow numerical modelling reaches 1.0 at $37.49 \mathrm{kPa}$ (Quan Luna et al., 2011). However, On the basis of field investigation, Zanchetta et al. (2004) concluded that most buildings are completely devastated when the impact pressure is higher than $90 \mathrm{kPa}$, which is close to the experimental result of Wei et al. (2006). It is possible that the impact pressure obtained from the field investigation or experimental measurement is higher than that calculated by the numerical model because the former reaches the maximum impact pressure at some points.

\section{Conclusions}

Damage to civil structures by debris flows causes considerable casualties and property loss. A feasible model of quantitatively assessing such damage is still under development because many factors such as a building's structure, material, and geometry, strongly influence the damage it experiences. More case studies can help people understand the characteristics and patterns of damage to buildings and help develop a quantitative vulnerability assessment model for debris-flow hazards. The Zhouqu debris flows on 7 August 2010 damaged several buildings with different structures and provided valuable information on building damage. Qualitative analysis of eight typical buildings damaged in the event shows that the damage to buildings has four characteristics: frontal impact by proximal debris flows, lateral accumulation and abrasion by distal debris flows, the boundary decreasing effect, and the back shielding effect. Impact, accumulation, and abrasion were the three main patterns of damage to buildings in this event, and they occurred concurrently in some cases. Reinforced concrete structures can effectively resist much greater debris-flow impact than brick-concrete structures. With respect to these two structures, five damage classes, ranging from very slight to complete, were defined on the basis of the extent of structural damage or accumulation. The five classes were divided into three damage scales, which were quantified by different critical values of impact pressure for brick-concrete and reinforced concrete structures.
Acknowledgements. This work has been supported by the National Basic Research Program of China (973 Program) (Grant No. 2011CB409902), Project Group of Knowledge Innovation Program of Chinese Academy Sciences (Grant No. KZCX2-YWQ03-5), and the Hundred Young Talents Program of the Institute of Mountain Hazards and Environment. The authors are also grateful to Sven Fuchs and another anonymous reviewer for their beneficial comments.

Edited by: O. Katz

Reviewed by: S. Fuchs and R. Sulpizio

\section{References}

Barbolini, M., Cappabianca, F., and Sailer, R.: Empirical estimate of vulnerability relations for use in snow avalanche risk assessment, in: Risk analysis IV, edited by: Brebbia, C., WIT Press, Southampton, 533-542, 2004.

Evans, S. G., Bishop, N. F., Smoll, L. F., Murillo, P. V., Delaney, K. B., and Oliver-Smith, A.: A re-examination of the mechanism and human impact of catastrophic mass flows originating on Nevado Huascarán, Cordillera Blanca, Peru in 1962 and 1970, Eng. Geol., 108, 96-118, 2009.

Fuchs, S., Heiss, K., and Hübl, J.: Towards an empirical vulnerability function for use in debris flow risk assessment, Nat. Hazards Earth Syst. Sci., 7, 495-506, doi:10.5194/nhess-7-4952007, 2007.

Haugen, E. D. and Kaynia, A. M.: Vulnerability of structures impacted by debris flow, Landslides and Engineered Slopes, edited by: Chen, Z., Zhang, J.-M., Ho, K., Wu, F.-Q., and Li, Z.-K., Taylor and Francis Group, London, 381-387, 2008.

Holub, M., Suda, J., and Fuchs, S.: Mountain hazards: reducing vulnerability by adapted building design, Environ. Earth Sci., in press, online first, doi:10.1007/s12665-011-1410-4, 2012.

Hu, K. H., Ge, Y. G., Cui, P., Guo, X. J., and Yang, W.: Preliminary analysis of extra-large scale debris flow disaster in Zhouqu County of Gansu Province, J. Mountain Sci., 28, 628-634, 2010 (in Chinese).

Jakob, M., Stein, D., and Ulmi, M.: Vulnerability of buildings to debris flow impact, Nat. Hazards, 60, 241-261, 2012.

Michael-Leiba, M., Baynes, F., Scott, G., and Granger, K.: Regional landslide risk to the Cairns community, Nat. Hazards, 30, 233249, 2003.

Mileti, D. S., Bolton, P. A., Fernandez, G., and Updike, R. G.: The eruption of Nevado del Ruiz Volcano, Colombia, South America, November 13, 1985, Natural disasters study, Volume Four, National Academy Press, Washington D C, 1991.

Mizuyama, T. and Ishikawa, Y.: Prediction of debris flow prone areas and damage, In: Hydraulics/Hydrology of Arid Lands (H2AL), Proceedings International Symposium, edited by: French, R. H., American Society of Civil Engineers, New York, 712-717, 1990.

Pierson, T. C., Janda, R. J., Thouret, J., and Borrero, C. A.: Perturbation and melting of snow and ice by the 13 November 1985 eruption of Nevado del Ruiz, Colombia, and consequent mobilization, flow and deposition of lahars, J. Volcanol. Geoth. Res., 41, 17-66, 1990.

Qu, X., Zhang, T., Liu, X., Zhou, Q., and Zhang, X.: Analysis on the meteorological causes for the 8 August 2010 massive mudslide in 
Zhouqu, Gansu Province, Meteorol. Month., 36, 102-105, 2010 (in Chinese).

Quan Luna, B., Blahut, J., van Westen, C. J., Sterlacchini, S., van Asch, T. W. J., and Akbas, S. O.: The application of numerical debris flow modelling for the generation of physical vulnerability curves, Nat. Hazards Earth Syst. Sci., 11, 2047-2060, doi:10.5194/nhess-11-2047-2011, 2011.

Spence, R. J. S., Baxter, P. J., and Zuccaro G.: Building vulnerability and human casualty estimation for a pyroclastic flow: a model and its application to Vesuvius, J. Volcanol. Geoth. Res., 133, 321-343, 2004.

Totschnig, R., Sedlacek, W., and Fuchs, S.: A quantitative vulnerability function for fluvial sediment transport, Nat. Hazards, 58, 681-703, 2011.

Toyos, G., Oppenheimer, C., Pareschi, M. T., Sulpizio, R., Zanchetta, G., and Zuccaro, G.: Building damage by debris flows in the Sarno area, Southern Italy, in: Proceedings of the Third International Conference on Debris-Flow Hazards Mitigation: Mechanics, Prediction and Assessment, edited by: Rickenmann, D. and Chen, C.-L., Millpress, Rotterdam, Netherlands, 1209-1220, 2003.

Valentine, G. A.: Damage to structures by pyroclastic flows and surges, inferred from nuclear weapons effects, J. Volcanol. Geoth. Res., 87, 117-140, 1998.

Wei, F. Q., Xie, H., and Lopez, J. L.: Extraordinarily serious debris flow disasters in Venezuela in 1999, J. Mountain Sci., 18, 580582, 2000 (in Chinese).
Wei, F. Q., Zhang Y., Hu, K. H., and Gao, K. C.: Model and method of debris flow risk zoning based on momentum analysis, Wuhan University, J. Nat. Sci., 11, 835-839, 2006.

Wieczorek, G. F., Larsen, M. C., Eaton, L. S., Morgan, B. A., and Blair, J. L.: Debris-flow and flooding hazards associated with the December 1999 storm in coastal Venezuela and strategies for mitigation, US Geological Survey, Open File Report 01-0144, 2001.

Wilhelm, C.: Quantitative risk analysis for evaluation of avalanche protection projects, in: Proceedings of 25 Years of Snow Avalanche Research, Oslo, Norway, 288-293, 1998.

Wu, J. S., Tian, L. Q., Kang, Z. C., Zhang, Y. F., and Liu, J.: Debris flow and its comprehensive control, Science Press, Beijing, 188225, 1993 (in Chinese).

Zanchetta, G., Sulpizio, R., Pareschi, M. T., Leoni, F. M., and Santacroce, R.: Characteristics of May 5-6, 1998 volcaniclastic debris-flows in the Sarno area of Campania, Southern Italy: relationships to structural damage and hazard zonation, J. Volcanol Geoth. Res., 133, 377-393, 2004.

Zaporozhchenko, E. V.: Debris-flow hazards in the Baksan river basin, Tyrnyauz, Russia, in: Proceedings of the Third International Conference on Debris-Flow Hazards Mitigation: Mechanics, Prediction and Assessment, edited by: Rickenmann, D. and Chen, C.-L., Millpress, Rotterdam, Netherlands, 1059-1070, 2003.

Zhao, Y. C. and Cui, C. G.: A study of rainstorm process triggering Zhouqu extremely mudslide on 8 August 2010, Torrent. Rain Disast., 9, 289-295, 2010 (in Chinese). 